OUPBOATE

\title{
PROPOSED TRUPACT-II CRITERIA FOR GAS GENERATION
}

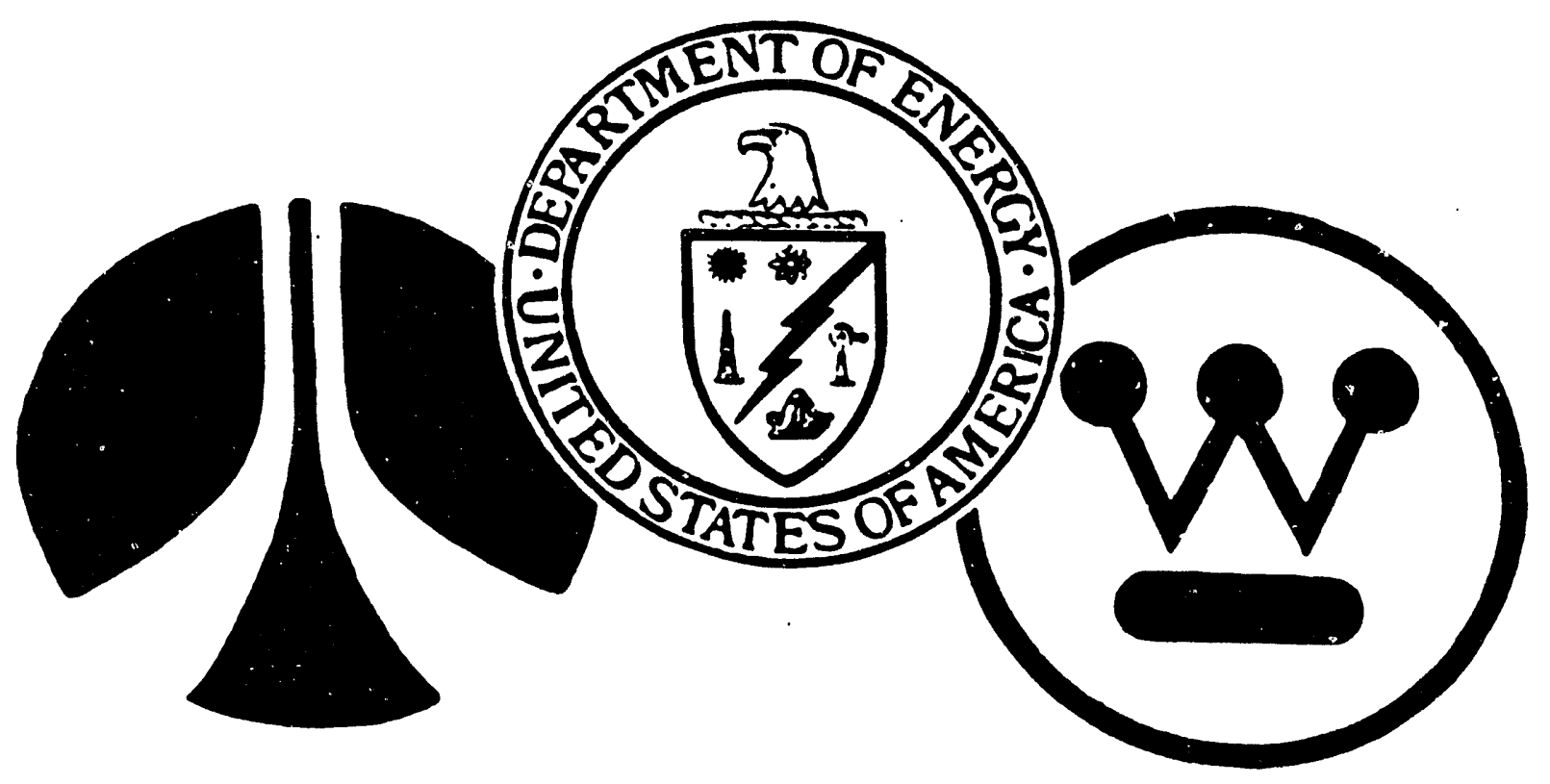

DEPARTMENT OF ENERGY

ROCKWELL INTERNATIONAL

WESTINGHOUSE

JOINT INTEGRATION OFFICE

ALBUQUERQUE, N.M.

NOVEMBER 1986 
NOTICE: This report was prepared as an account of work sponsored by an agency of the United States Government. Neither the United States Government nor any agency thereof, nor any of their employees, makes any warranty, express or implied, or assumes any legal liability or responsibility for the accuracy, completeness, or usefulness of any information, apparatus, product, or process disclosed, or represents that its use would not infringe privately owned rights. Reference herein to any specific commercial product, process, or otherwise, does not necessarily constitute or imply its endorsement, recamendation, or favoring by the United States Government or any agency thereof. The views and opinions of authors expressed herein do not necessarily reflect those of the Inited States Government or any agency thereof. 
DOE/J IO- -016

DE92 000882

\title{
PROPOSED TRUPACT-II CRITERIA \\ FOR GAS GENERATION
}

\author{
DEFENSE TRANSURANIC WASTE PROGRAM \\ JOINT INTEGRATION OFFICE \\ Operated by \\ Rockwell International Corporation \\ and \\ Westinghouse Electric Corporation \\ for the \\ United States Department of Energy \\ Under Contract DE-ACO4-75DP03533
}

November 1986
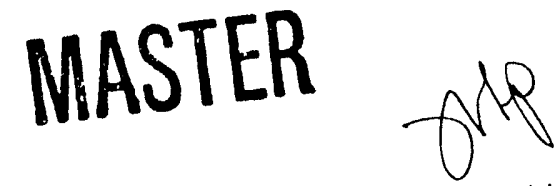

DICTRIRIJTION OF THIS DOCUMENT IS UNLIMITED 


\section{PREFACE}

For the purpose of providing recommended design assumptions for TRUPACT-II, gas generation within the TRU waste containers and the potential effects resulting from the absence of continuous venting of the TRUPACT-II are considered in this report. The recommended assumptions are based on the best current state of knowledge to conservatively represent the potential gas generation loads for the TRUPACT-II.

The work incurred with the compiling of data and study of this issue was provided by Science Applications International Corporation (SAIC) in Pleasanton, California and is supported by the United States Department of Energy, Joint Integration Office. Reviews were provided by Sandia National Laboratory and the TRUPACT Task Force. 
Page

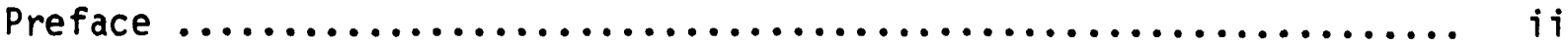

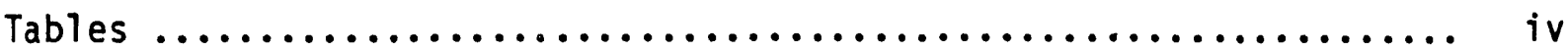

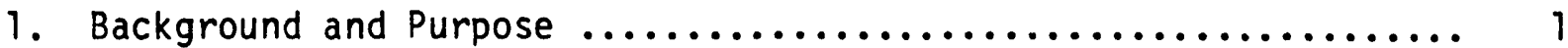

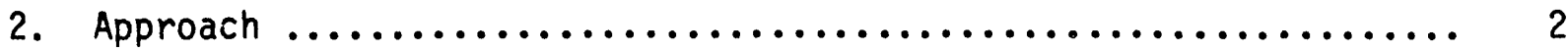

3. Summary of Recommended Assumptions $\ldots \ldots \ldots \ldots \ldots \ldots \ldots \ldots \ldots$

4. Radiolytic Gas Yield .............................. 4

4.1 Recommended Values ............................. 4

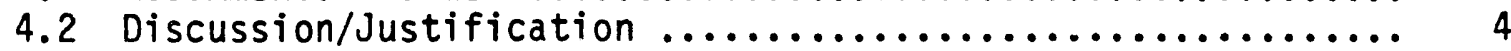

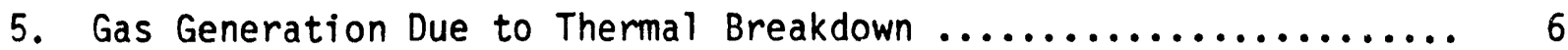

5.1 Recommended Values ............................... 6

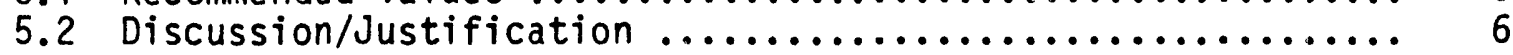

6. Gas Generation Due to Bacterial Breakdown ................ 9

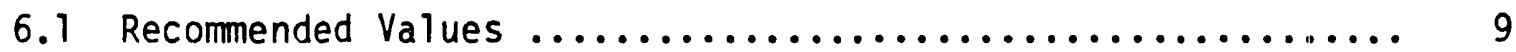

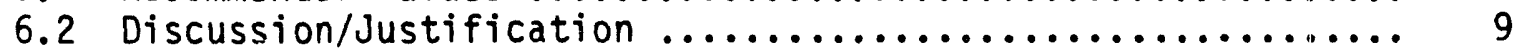

7. Radiolytic Oxygen Depletion ......................... 11

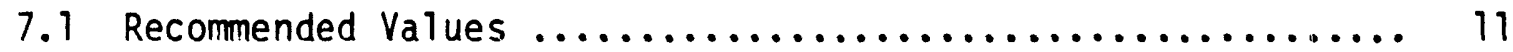

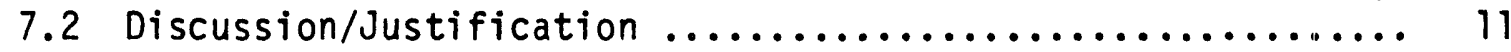

8. Container Void Volume and Residual water Content ............ 13

8.1 Recommended Values ............................... 13

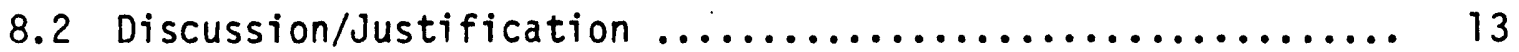

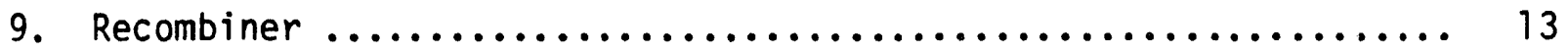

9.1 Recommended Values $\ldots \ldots \ldots \ldots \ldots \ldots \ldots \ldots \ldots \ldots \ldots \ldots \ldots \ldots$

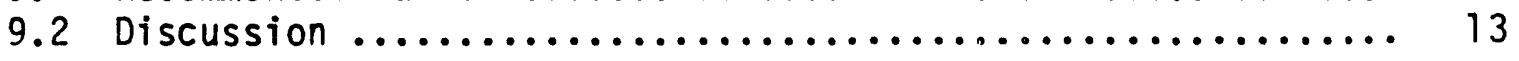

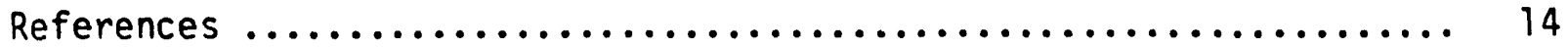


TABLES

Page

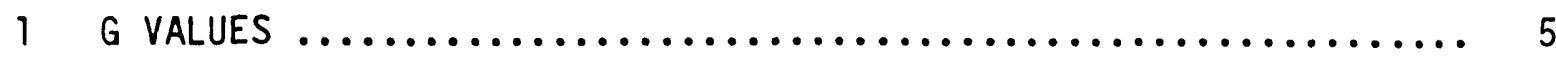

2 TENTATIVE GAS GENERATION RATES FROM THERMAL DEGREDATION ...... 7

3 APPROXIMATE GAS COMPOSITION FROM THERMAL DEGREDATION AT 70 OC $\ldots 8$

4 NET BACTERIAL $\mathrm{CO}_{2}$ GAS GENERATION FOR VARIOUS ENVIRONMENTS $\ldots \ldots .10$

5 RADIOLYTIC HYDROGEN PRODUCTION/OXYGEN CONSUMPTION ........... 12 
1. Background, and Purpose

TRUPACT-II is an updated design for the TRUPACT shipping container for TRU wastes. The TRUPACT-II differs from previous designs in that the absence of continuous venting is anticipated as a design characteristic. As a result, gas generation within the vented TRU waste containers is a potentially important issue. TRU waste gas generation can impact the TRUPACT-II design for several reasons:

-- Radiolytic, thermal, chemical and bacterial gas generation in an unvented TRUPACT-II can result in the accumulation of combustible gas mixtures (e.g., hydrogen and oxygen) thereby suggesting the use of hydrogen removal methods such as recombiners and/or getters.

-- Gas generation in an unvented TRUPACT-II can result in the buildup of pressure within the TRUPACT-II which may require structural enhancements and/or the use of pressure relief devices to increase the pressure capacity.

-- High temperatures within the TRUPACT-II due to radioactive decay heat and external thermal loading may result in an enhanced level of gas generation due to thermal degradation.

-- Oxygen depletion due to radiolysis as well as bacterial, chemical and thermal degradation may impact on the performance of a hydrogen recombiner.

To ensure that the TRUPACT-II design activities can proceed expeditisusly in light of these issues, it is necessary to develop a set of recommended assumptions regarding gas generation to be used in design assessments. The intent of these gas generation design criteria inputs is to provide recommended assumptions reflecting the best current state of knowledge to conservatively represent the potential gas generation loads for the TRUPACT-II. 


\section{Approach}

Two sets of criteria are recognized to apply to the gas generation issue for the TRUPACT-II design. First, the USNRC in IE Information Notice No. 84-72 requires that flammable gas mixtures $\left(\mathrm{H}_{2}>5 \%\right.$ and $\left.\mathrm{O}_{2}>5 \%\right)$ be avoided during a period of time up to twice the expected shipping period. For truck and rail shipping times of 15 and 30 days, respectively, this corresponds to control periods of 30 and 60 days.

The second set of criteria relates to the requirements to design for the "Maximum Normal Operating Pressure" (MNOP) under 10 CFR 71. Although a pressure accumulation period of one year under continuing adverse environmental thermal loading appears to be highly improbable, 10 CFR 71 indicates that this should be used in the basis for pressure design.

Consequentiy, two sets of calculational assumptions have been developed and recommended in this document. The first of these is the "30-60 day worst realistic case" set of assumptions that are recommended for application principally during expected shipping conditions (i.e., those anticipated during the 30 and 60 day time periods). The second set of calculational assumptions is the "Design Basis" set. These assumptions are recommended for application in developing the MNOP which assumes a 1 year pressure accumulation period.

Due to limitations on the existing state of knowledge, a certain degree of engineering judgment is required in the development of appropriate criteria. Consequently, the format of the recommendations includes a statement of the recommended values followed by a discussion of the basis or rationale for them. 


\section{Summary of Recommended Assumptions}

The following summarizes the recommended assumptions for TRUPACT-II design assessments based on a $60^{\circ} \mathrm{C}$ temperature:

Parameter 30-60 Day Worst Case Regulatory Design Basis

Radiolytic gas generation

G (Total)

G (Hydrogen)

Thermal gas $\left(\mathrm{CO}_{2}\right)$ generation

Bacterial gas generation

Void volume

Water vapor

Catalytic recombiner
36 drums at $\mathrm{GT}_{\mathrm{T}}=2.9$

36 drums at $G_{H}=1.9$

36 drums at 2.6 moles/ drum/yr

36 drums at 4.2 moles/
drum/yr

$50 \%$ (average)

saturation

yes
36 drums at $G_{T}=1.45$

36 drums at $G_{H}=0.95$
36 drums at 2.6 moles/ drum/yr

2 drums at 4.2 moles/ drum/yr

$50 \%$ (average)

saturation

yes

Each of these parameters is addressed in subsequent sections with recommendations and corresponding discussion/justification. 


\section{Radiolytic Gas Yield}

4.1 Recommended Values:

Worst Realistic Case

$G($ total $)=2.9$

$G($ hydrogen $)=1.8$
Design Basis

$G($ total $)=1.45$

$G($ hydrogen $)=0.95$

\subsection{Discussion/Justification}

Radiolytic gas yields ( $G$ values) for a number of common waste materials have been extracted from the literature by Molecke [1] and are summarized in Table 1. The values shown for several materials were obtained from more than one source and, for the most part, correlate fairiy well.

The majority of matrix materials in Table 1 have $G_{\text {total }}$ values which are less than 2.9 and $G_{H_{2}}$ values not exceeding 1.8. The most notable exception is PVC as reported by Ryan [2] using Los Alamos data. Zerwekh [3] has reported that the PVC data has been misinterpreted and that RFP values are more reasonable.

The data indicate that $G$ values of 2.9 (total) and 1.8 (hydrogen) molecules/100eV are appropriate as conservative upper limits based on currently available data for waste types expected to be shipped to WIPP and are recommended as a basis for the 30-60 day worst case set of assumptions. Exotic wastes such as oil sorbed on microcell $\left(G_{\text {total }}=3.1\right)$ or octane sorbed on vermiculite $\left(G_{\text {total }}=4.5\right)$ would be expected to be shipped concurrently with low G-value drums to maintain the TRUPACT-II average $G$ values less than the assumed worst case values. Note also that waste forms containing large quanticies of free liquids are not allowed by the waste acceptance criteria for WIPP. 
Table 1

G Values

(based on data from Molecke [1] and Ryan [2])

\begin{tabular}{|c|c|c|c|}
\hline Matrix & Source & $G_{\text {total }}$ (molecules/100eV) & $\mathrm{GH}_{2}($ molecules $/ 100 \mathrm{eV})$ \\
\hline \multirow[t]{3}{*}{ Cellulosics } & LASL & $1.3-2.9$ & $0.8-1.7$ \\
\hline & SRL & 1.9 & 0.95 \\
\hline & RFP & .31 (wet) -.63 (dry) & 0.19 (wet) -0.38 (dry) \\
\hline \multirow[t]{2}{*}{ PVC } & LASL & $8-11^{\star \star}$ & $7.2 \cdots 9.9 \star \star$ \\
\hline & RFP & $0.43-0.96$ & $0.39-0.86$ \\
\hline \multirow[t]{2}{*}{ Polyethylene } & LASL & 1.9 & 1.8 \\
\hline & RFP & 0.73 & 0.66 \\
\hline \multirow[t]{3}{*}{ Pump 0 il } & LASL & $1.3-1.8$ & $1.0-1.4$ \\
\hline & SRL & 2.0 & 1.6 \\
\hline & RFP & $3.1 * \star \star$ & 2.5 \\
\hline Asphalt & LASL & $0.2-1.0$ & N/A \\
\hline Octane & SRL & 4.5 & $N / A$ \\
\hline Concrete TRU Ash & SRL & $0.0003-0.6$ & $N / A$ \\
\hline Plexiglas & RFP & 1.9 & $N / A$ \\
\hline Rubber & RFP & 0.37 & N/A \\
\hline S. udge & RFP & $.078-.873$ & $0.026-0.14$ \\
\hline
\end{tabular}

$N / A=$ not available.

LASL = Los Alamos Scientific Laboratory

SRL = Savannah River Laboratory

RFP = Rocky Flats Plant

*The $G$ values for hydrogen were calculated from gas composition data reported by Molecke [1] and Ryan [2] as appropriate.

** It has been reported [3] that these values should not be relied upon for PVC. The RFP values should be used.

$\star \star \star$ Reported as oil. 
Recognizing the fact that an actual TRU waste shipment will contain a mixture of TRU waste containers, some of which may not generate any significant levels of radiolytic gas, and taking into consideration the very conservative nature of the $G$ values discussed above, a more realistic set of G-values at $50 \%$ of the worst case levels is recommended for the MNOP design basis.

\section{Gas Generation Due to Thermal Breakdown}

5.1 Recommended Values

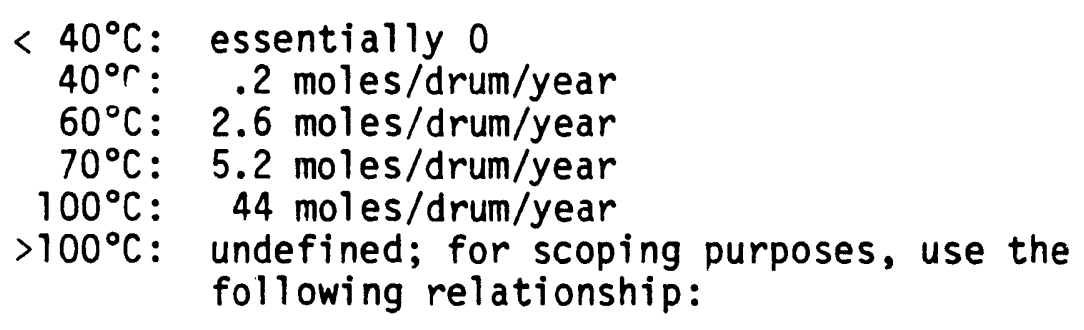

$$
\begin{aligned}
& R=44 e^{(T-100) \frac{\ln 2}{10}} \\
& \text { where } T \text { is temperature in }{ }^{\circ} \mathrm{C}
\end{aligned}
$$

Hydrogen Fraction: $14 \%$

Oxygen Fraction: $7 \%$

\subsection{Discussion/Justification}

Information on gas generation due to thermal breakdown is very limited. The recommended values are based on data summarized by Molecke [1]. Tables 2 and 3 present the relevant data. From Table 2 the maximum values observed/ estimated at $40^{\circ}, 70^{\circ}$, and $100^{\circ}$ are recommended as conservative design values. The relationship given above is based on the assumption that thermal degrada- tion reactions will double for each $10^{\circ} \mathrm{C}$ increment of temperature increase [1]. This relationship allows for interpolation of rates that might be expected below the $100^{\circ} \mathrm{C}$ level, and should be used with caution for 
Table 2

TENTATIVE GAS GENERATION RATES FROM THERMAL DEGRADATION*

(Average drum $=51.4 \mathrm{~kg}$ of waste matrix)

\begin{tabular}{lccc}
\hline Matrix & Gas Generation Rate (moles/year/drum) \\
\hline & $100^{\circ} \mathrm{C}$ & $70^{\circ} \mathrm{C}$ & $40^{\circ} \mathrm{C}$ \\
Paper & -- & 1.3 & $\star \star$ \\
Composite & 44 & -- & $\star \star$ \\
Polyethylene & - & 1.9 & $\star \star$ \\
Cotton & -- & 5.2 & \\
\hline
\end{tabular}

*Data obtained from laboratory experiments with simulated wastes.

$\star \star$ Estimated at $0.02-0.2 \mathrm{~mole} /$ year $/ \mathrm{drum}$

Taken from Molecke [1]. 
projections above that level. Note that, for temperatures less than $100^{\circ} \mathrm{C}$, the relation- ship gives results that are somewhat greater than the specific values recom- mended for $40^{\circ} \mathrm{C}, 60^{\circ} \mathrm{C}$, and $70^{\circ} \mathrm{C}$. The value given for $60^{\circ} \mathrm{C}$ is based on a factor of 2 reduction from the $70^{\circ} \mathrm{C}$ value. The value given at $100^{\circ} \mathrm{C}$ is based on a single data point for a composite waste form. Chemical breakdown of organics, dewatering of cements, and volatilization of water and organic absorbed liquids are components of thermal gas generation, and can be expected to take place at differing rates depending on the waste forms present. Above $70^{\circ} \mathrm{C}$, these reactions become increasingly important and are difficult to predict in a "generic" waste form. Note that bacterial generation may also be included in the experinental measured thermal generation rates for $40^{\circ} \mathrm{C}$ and $70^{\circ} \mathrm{C}$.

Table 3 presents data on gas compositions from thermal degradation at $70^{\circ} / 100^{\circ} \mathrm{C}$. The recommended value for hydrogen fraction is the maximum reported value. The recommended value for oxygen fraction is the value that corresponds to the hydrogen maximum.

Table 3

APPROXIMATE GAS COMPOSITIONS FROM THERMAL DEGRADATION AT $70^{\circ} \mathrm{C}$ (mole percent)

\begin{tabular}{lccccc}
\hline & $\mathrm{CO}_{2}$ & $\mathrm{CO}$ & $\mathrm{H}_{2}$ & $\mathrm{O}_{2}$ & $\mathrm{CH}_{4}$ \\
Paper & $80 \%$ & $19 \%$ & - & $1 \%$ & $\ldots$ \\
Cotton & $31 \%$ & $11 \%$ & $(1 \%)$ & $58 \%$ & - \\
Composite $\left(100^{\circ} \mathrm{C}\right)$ & $76 \%$ & $3 \%$ & $14 \%$ & $7 \%$ & $(1 \%)$ \\
Polyethylene & $3 \%$ & $1 \%$ & $3 \%$ & $93 \%$ & $\ldots$ \\
\hline
\end{tabular}

Taken from Molecke [1]. 
6. Gas Generation Due to Bacterial Breakdown

\title{
6.1 Recommended Values
}

\author{
Aerobic Conditions: 4.2 moles/year/drum \\ Anaerobic Conditions: 7.3 moles/year/drum \\ Composition: $\mathrm{CO}_{2}$
}

30-60 day worst case assumption: 36 drums at maximum aerobic generation leve1 Regulatory Design basis: 2 drums at maximum aerobic generation level

\subsection{Discussion/Justification}

Molecke [1] summarizes data for bacterial gas generation for various environments, temperatures, and conditions with regard to available oxygen (Table 4 ). The gas generation rates were collected in laboratory experiments with simulated waste matrices under ideal conditions. The recommended values are based on the maximum generation rates reported for aerobic and anaerobic conditions for environments other than brine. For temperatures up to $70^{\circ} \mathrm{C}$, these values appear to be appropriate for design assumptions for anticipated waste forms. Above $70^{\circ} \mathrm{C}$, the bacterial generation term is expected to drop rapidly and become much less important than thermal generation at $100^{\circ} \mathrm{C}$. The values reported for bacterial breakdown were corrected for thermal effects by the subtraction of thermal generation "background" measured with experimental control samples.

For purposes of 30-60 day worst case assessment, the recommended assumption is that all 36 drums in a loaded TRUPACT-II are generating gas at the maximum rate for aerobic conditions. For the regulatory design basis assumption, it is recognized that current waste management experience indicates that, at most, only a small fraction of TRU waste containers experience significant continuous bacterial gas generation. Thus, 2 drums per TRUPACT-II (or 6\% of the load) are assumed to generate gas by bacterial breakdown. 
Table 4

NET BACTERIAL $\mathrm{CO}_{2}$ GAS GENERATION FOR VARIOUS ENVIRONMENTS

(Moles/Year/Container)

\begin{tabular}{|c|c|c|c|c|c|c|c|}
\hline & & $25^{\circ} \mathrm{C}$ & $40^{\circ} \mathrm{C}$ & $70^{\circ} \mathrm{C}$ & $25^{\circ} \mathrm{C}$ & $40^{\circ} \mathrm{C}$ & $70^{\circ} \mathrm{C}$ \\
\hline \multicolumn{2}{|c|}{ Environment } & \multicolumn{3}{|c|}{ Aerobic } & \multicolumn{3}{|c|}{ Anaerobic } \\
\hline & & \multicolumn{6}{|c|}{ LASL Composite $(51.4 \mathrm{~kg} / \mathrm{drum})$} \\
\hline Water, Sat & & 1.6 & 1.8 & 3.1 & 4.2 & 0.6 & 3.4 \\
\hline Brine & : & $(0)$ & 5.2 & 5.5 & 1.2 & 7.8 & $(0)$ \\
\hline Nutrient & : & 3.1 & 1.5 & (0) & 3.6 & 1.4 & 7.3 \\
\hline Water, $1 \%$ & : & $(0)$ & 1.3 & 4.2 & 0.3 & 2.6 & 2.5 \\
\hline
\end{tabular}

Taken from Molecke [1]. 


\section{Radiolytic Oxygen Depletion}

i.l Recommended Values

$$
\mathrm{G}_{2}=-1.0
$$

Depletion of oxygen should be considered only when it is conservative to do so.

\subsection{Discussion/Justification}

The radiolytic oxygen depletion $G$ factors have been calculated from data reported by Kazanjian [4] and are found to vary from -.28 to -4.7 molecules/100eV for a variety of waste materials. Individual values for $\mathrm{G}_{\mathrm{H}_{2}}$ and $\mathrm{G}_{2}$ determined for several materials are given in Table 5 .

Since a typical TRU waste container will contain several materials, an organic composite waste form consisting of $35 \%$ cellulosics, $23 \%$ polyethylene, 12\% polyvinyl chloride, and 30\% rubber [1] was evaluated. The composite $\mathrm{G}_{2}$ ranges from -.49 to -.97 .

For purposes of design conservatism, a value of $G_{0}=-1.0$ is recommended where oxygen depletion is a detriment. The oxygen depletion term should be considered to be included in the total gas generation rate. 
Table 5

RADIOLYTIC HYDROGEN PRODUCTION/OXYGEN CONSUMPTION*

\begin{tabular}{|c|c|c|c|}
\hline 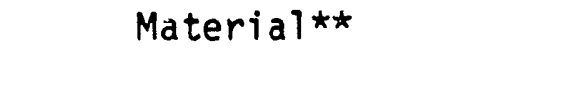 & $\mathrm{GH}_{2}$ & \multicolumn{2}{|c|}{$\mathrm{G}_{2}$} \\
\hline Dry cellulosics (Kimwipes) & .55 & \multicolumn{2}{|c|}{-.69} \\
\hline Wet cellulosics (Kimwipes) & .32 & \multicolumn{2}{|c|}{-.28} \\
\hline Polyethylene & .75 & \multicolumn{2}{|c|}{-.28} \\
\hline PVC & $.35-.81$ & -1.0 & -2.3 \\
\hline Gloves, rubber & $.26-.39$ & -.69 & $-1 \cdot 3$ \\
\hline $0 i 1$ & 2.9 & \multicolumn{2}{|c|}{-.59} \\
\hline $\mathrm{CCl}_{4}$ & 0 & \multicolumn{2}{|c|}{-2.0} \\
\hline Chloroethene VG & .24 & \multicolumn{2}{|c|}{-2.8} \\
\hline IX Resin & .077 & \multicolumn{2}{|c|}{-.53} \\
\hline Plexiglass & .49 & \multicolumn{2}{|c|}{-4.7} \\
\hline
\end{tabular}

*G Ialues were calculated from gas generation data reported by Kazanjian [4].

**Some of these materials may not be acceptable for disposal at WIPP without processing/solidification. 


\title{
8. Container Void Volume and Residual Water Content
}

\subsection{Recommended Values}

\author{
Void Volume: 50\% (baseline) \\ $15 \%$ - 90\% (range) \\ Water content: sufficient to maintain saturation at $60^{\circ} \mathrm{C}$
}

\subsection{Discussion/Justification}

Observed void volumes generally fall within the given range for a single container and are highly dependent on the waste material type. For a TRUPACT-II shipment, the baseline $50 \%$ void volume assumption is recommended as an average over the entire load for both the 30-60 day worst case and the regulatory design basis case.

Specifications (acceptance criteria) for water and other free liquids are very restrictive, but liquids absorbed in materials such as vermiculite can be substantial. The assumption that water is present in sufficient quantity to maintain saturated conditions at $60^{\circ} \mathrm{C}$ is recommended so that pressurization due to water vaporization is accounted for in design assessments.

\section{Recombiner}

9.1 Recommended values:

$\mathrm{H}_{2}$ is removed as soon as it reaches the recombiner medium. The reaction proceeds as long as both $\mathrm{H}_{2}$ and $\mathrm{O}_{2}$ are present. $1 \mathrm{ml}$ of catalyst is required to remove $1 \mathrm{ml} \mathrm{H}_{2}+\mathrm{O}_{2}$ per hour at STP. Catalyst bed should be $1 \mathrm{~cm}$ thick.

\subsection{Discussion}

The above recommendations are based on information developed at Rockwell Hanford [5] for catalytic recombiners. 


\section{REFERENCES}

[1] M. A. Molecke, "Gas Generation from Transuranic Waste Degradation: Data Summary and Interpretation," SAND 79-1245, Sandia National Laboratories, Albuquerque, New Mexico, December 1979.

[2] J. P. Ryan, "Radiogenic Gas Accumulation in TRU Waste Storage Drums," DP-1604, Savannah River Laboratory, Aiken, South Carolina, January 1982.

[3] A. Zerwekh, "G Values for PVC," Los Alamos National Laboratory memorandum to B. Reich, 31 January 1985.

[4] A. B. Kazanjian, "Radiolytic Generation in Plutonium Contaminated Waste Materials," RFP-2469, Rockwell International, Atomics International Division, Rocky Flats Plant, Golden, Colorado, 29 October 1976.

[5] J. 0. Henrie et al., "Hydrogen Control in the Handling, Shipping and Storage of Wet Radioactive Waste," RHO-WM-EV-9P, Rockwell International, Rockwell Hanford Operations, Richland, Washington, December 1985. 

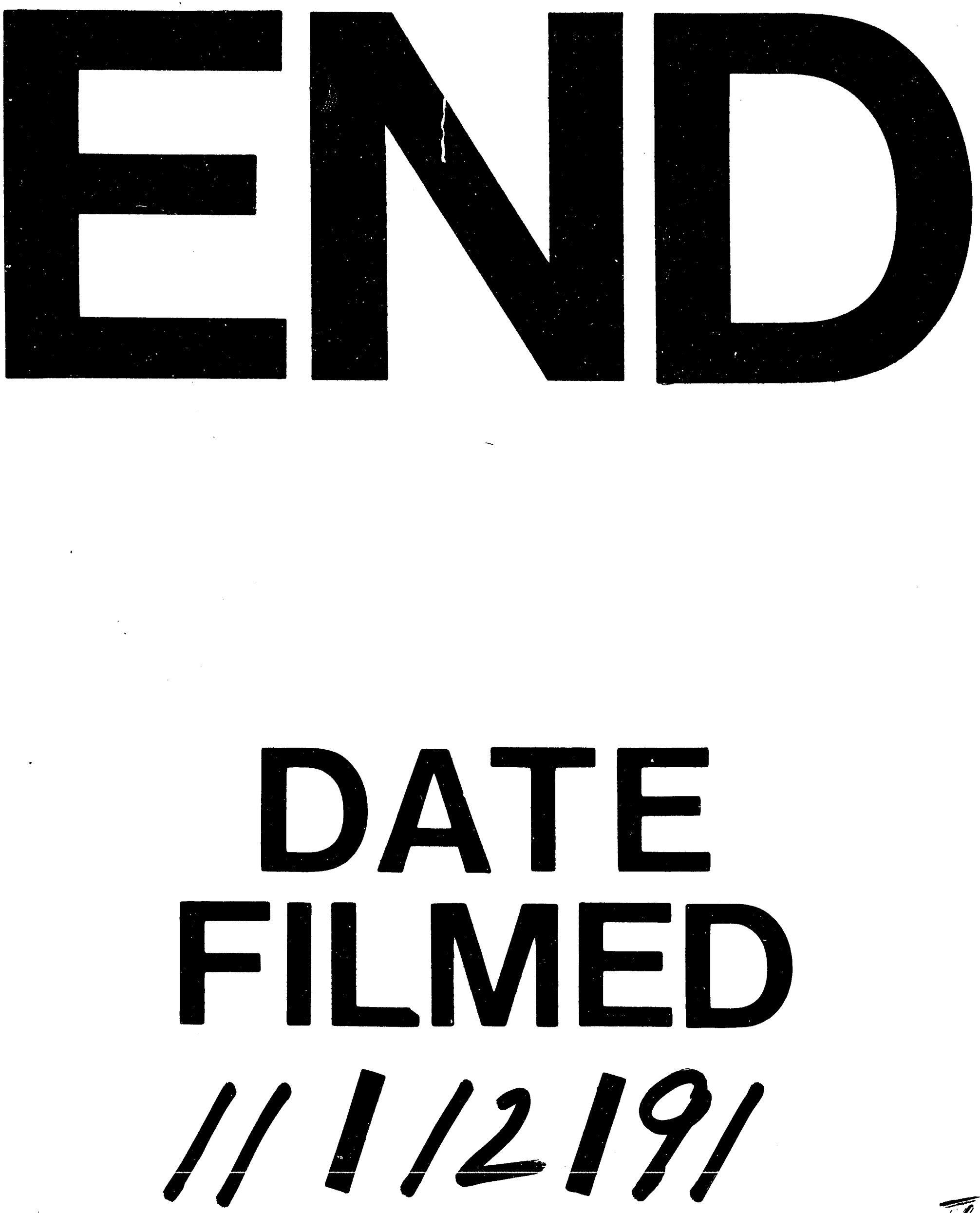

II 
